\title{
THE IMPORTANCE OF DETERMINING THE UROMODULIN SERUM CONCENTRATION IN DIABETES MELLITUS TYPE 2 PATIENTS
}

\author{
Jordanova Elena, ${ }^{1}$ Samardzic Vladimir, ${ }^{2}$ Pekovic-Perunicic Gordana, ${ }^{1}$ \\ Tica-Jevtic Jelena, ${ }^{2}$ Simic-Ogrizovic Sanja ${ }^{3,4}$ \\ ${ }^{1}$ Department of Nephrology, Clinic for Internal Medicine, Clinical Hospital Center Zemun, Belgrade, Serbia \\ ${ }^{2}$ Department of Endocrinology, Clinic for Internal Medicine, Clinical Hospital Center Zemun, Belgrade, Serbia \\ ${ }^{3}$ Medigroup Hospital, New Belgrade, Belgrade, Serbia \\ ${ }^{4}$ University of Banja Luka, School of Medicine, Banja Luka, Bosnia and Herzegovina
}

Primljen/Received 13. 11. 2021. god.

Abstract: Introduction: In the kidney, cells in the thick ascending limb of the loop of the Henle synthesized uromodulin (UMOD). This study aims to present the evaluation of the uromodulin serum concentration in diabetes mellitus type 2 (T2DM) patients in the early detection of kidney damage.

Materials and methods: The study included 50 T2DM patients mean age of $60.75 \pm 11.23$ years estimated glomerular filtration rate (eGFR) $114.38 \pm$ $22.12 \mathrm{ml} / \mathrm{min}$ and a control group of 20 healthy persons. We measured serum concentration of haemoglobin, urea, creatinine, uromodulin (ELISA method), and cystatin $\mathrm{C}$ (nephelometry). We determined formulas: Cockcroft-Gault\# (combination Cockcroft- Gault for patients with $\mathrm{BMI}<30 \mathrm{~kg} / \mathrm{m}^{2}$ and Cockcroft-Gault ${ }_{\mathrm{LBW}}$ for patients with BMI $\geq 30 \mathrm{~kg} / \mathrm{m} 2$ ), CKD-EPI (Chronic Kidney Disease Epidemiology Collaboration equation), and simple Cystatin C.

Results: T2DM patients had lower hemoglobin serum concentration as well as eGFR calculated by formulas: Cockcroft- Gault\# and CKD-EPI. T2DM patients had significantly higher BMI and cystatin $\mathrm{C}$ compared to control group. T2DM patients had significantly lower serum uromodulin concentration (136.51 \pm 84.34 vs $220.50 \pm 92.39 \mathrm{ng} / \mathrm{ml}$ ) than in controls. Significant positive correlation between uromodulin and Cockcroft- Gault\# ( $r=0.432, \mathrm{p}=0.000)$, CKD- EPI ( $\mathrm{r}$ $=0.439 ; \mathrm{p}=0.000$ ) formulas as well as simple cystatin $\mathrm{C}(\mathrm{r}=0.250, \mathrm{p}=0.02)$, but negative correlation with age $(r=-0.476, p=0.000)$, BMI $(r=-0.313, p=0.002)$ and cystatin $C$ serum concentration $(r=-0.293, p=$ 0.015) were found.

Conclusion: The role of serum uromodulin concentration is not still fortified. The results of this study
Prihvaćen/Accepted 11. 12. 2021. god.

showed that reduced uromodulin serum concentration indicated early kidney damage in T2DM patients.

Keywords: creatinine clearance, cystatin C, diabetes mellitus, eGFR, uromodulin.

\section{INTRODUCTION}

In the kidney, cells in the early distal tubule and the thick ascending limb (TAL) of the loop of the Henle synthesized uromodulin (UMOD). UMOD is an 80- $90 \mathrm{kDa}$ molecule, also known as Tamm Horsfall protein (1). This protein is transported to the apical plasma membrane and then released into the tubular fluid $(1,2)$.

The role that UMOD has in the kidney remains unclear, although nephrologists have been researching this protein for the past 50 years. This proves the need for a better understanding of the role of this protein in health and disease states $(3,4)$. Although the physiological role of uromodulin is not clearly defined, there is growing interest in determining this glycoprotein in serum and urine of patients with acute and chronic renal failure as a marker of renal function $(1,3,5)$.

In acute kidney injury (AKI), researchers showed a connection of UMOD to inflammation. A study by Säeman et al. (6) suggested a pro-inflammatory role of UMOD. Pfistershammer et al. (7) showed that scavenger receptors play a role in the anti-inflammatory effects of UMOD. El-Achkar and Wu (3) consider that during the AKI, on the basolateral side of the membrane, there is a change in the structure of uromodulin in the form of glycosylation and these changes determine whether the uromodulin will bind to one or another type of receptor, i.e. whether it will have a 
pro-inflammatory or anti-inflammatory effect. However, these authors support the anti-inflammatory effect of uromodulin.

Associations between the estimated glomerular filtration rate (eGFR) and stage of chronic kidney disease (CKD) and single-nucleotide polymorphism (SNP) in the UMOD gene were significant $(8,9)$. The minor T allele of the SNP confirmed a $20 \%$ reduction in risk for development of CKD that was shown in the Atherosclerosis Risk in Communities Study after 15 years of follow-up (10).

In the light of these findings and consequent potential diagnostic significance, this study aimed to evaluate the uromodulin serum concentration in patients with type 2 diabetes mellitus (T2DM) in the early detection of kidney damage.

\section{MATERIALS AND METHODS}

The study was approved by the institutional Ethical Committee and carried out following the principles of the Declaration of Helsinki. All patients comprehended in this study signed an informed consent form.

\section{Patients}

The cross-section study included 50 patients (18 males) with T2DM hospitalized in the Clinical Hospital Center Zemun, Clinic for Internal Medicine - Department of Nephrology. The controls were 20 healthy subjects. Participants were previously diagnosed with T2DM. The patients diagnosed with active neoplastic disease, autoimmune disease, the end stage of CKD, acute complications of T2DM, pregnancy, and acute urinary tract infection were excluded from the study. The duration of T2DM was $10.04 \pm 5.77$ years (range 5 - 30 years). The demographic characteristics of the patients and body mass index (BMI) were determined. Blood pleasure was measured in patients after 10 minutes of the rest period. Mean arterial pressure (MAP) was calculated according to the equation:

$\mathrm{MAP}=1 / 3(\mathrm{SBP}-\mathrm{DBP})+\mathrm{DBP}(11)$

SBP - systolic blood pressure, DBP - diastolic blood pressure

\section{Laboratory Methods}

The serum concentration of hemoglobin (the hematological analyzer - the Beckman Coulter HMX), serum concentration of urea, and creatinine (the biochemical analyzer DXC- 800 Beckman Coulter) were measured. Jaffe method was used to measure the serum creatinine. Creatinine clearance was determined during 24-hour collection period from the measure- ment of creatinine concentration in urine and serum sample. Then creatinine clearance was calculated:

eGFR $(\mathrm{ml} / \mathrm{min})=\frac{\text { Creatinine urine } \mathrm{x} \text { Days Urine Volumen }}{\text { Creatinine serum } \mathrm{x}(1440 \mathrm{~min}=24 \mathrm{~h})(12)}$

The estimated glomerular filtration rate (eGFR) was determined according to the equations:

1. Cockcroft- Gault\# - combination CockcroftGault for patients with BMI $<30 \mathrm{~kg} / \mathrm{m}^{2}$ and modificated Cockcroft-Gault $\mathrm{LBW}_{\mathrm{LW}}$ for patients with BMI $\geq 30$ $\mathrm{kg} / \mathrm{m}^{2}(13)$

A. Cockcroft- Gault

eGFR $=[((140-$ age $) \mathrm{x}$ body weight $)) /(72 \mathrm{xserum}$ creatinine) ] x 0.85 (correction factor for female) (13)

B. Cockcroft-Gault

$\mathrm{eGFR}=(140-$ age $) \times \mathrm{LBW} /$ serum creatinine $\mathrm{x}$ correction factor

(correction factor for male $=1.23$; correction factor for female $=1.04$ )

LBW $=9720 \times$ body weight $/ 6680+216 \times$ BMI for male

LBW $=9720 \times$ body weight $/ 8780+244 \times$ BMI for female (14)

2. CKD - EPI (Chronic Kidney Disease Epidemiology Collaboration equation) (15)

$\mathrm{eGFR}=141 \mathrm{x} \min (\mathrm{SCr} / \kappa, 1)^{\alpha} \times \max (\mathrm{SCr} / \kappa, 1)^{-1.209}$ x $0.993^{\text {age }}$ x 1.018 [female] x 1.159 [black]

Serum uromodulin was measured by ELISA method- test Euroimmune (Medizinische Labordiagnostica AG) (3). The cystatin C level was determined by immunonephelometric method commercially test $\mathrm{N}$ latex cystatin $\mathrm{C}$ using nephelometar BN II Sistems Assays (Siemens Healthcare). Simple cystatin C was calculated according to formula: 100/ serum cystatin C (16).

\section{Statistical Analysis}

The normal distribution of the variables was proved by the Kolmogorov-Smirnov test. The student's t-test and Pearson's $\chi 2$ test were used to analyze data. Relationships between variables were estimated using univariate and multivariate regression. Receiver operating curve (ROC) was used to detect the ideal values (cut-off points) in diagnostics i.e. separating T2DM patients from healthy subjects. SPSS software (version 10) was used to perform statistical analysis. The conventional p-value was used; all levels of significance were set as $\mathrm{p}<0.05$.

\section{RESULTS}

Table 1 presents the demographic and clinical parameters clinical in the two patient groups. T2DM 
Table 1. Demographic and clinical parameters in the two patient groups

\begin{tabular}{|l|c|c|c|}
\hline Variable X $(\mathrm{SD})$ & $\mathrm{T}^{2} \mathrm{DM}^{\$}$ & Control group & Significance $\mathrm{p}$ \\
\hline Age $($ years $)$ & $60.75 \pm 11.23$ & $30.80 \pm 8.34$ & $\mathrm{p}<0.01$ \\
\hline Sex $(\mathrm{m} / \mathrm{f})$ & $18 / 32$ & $9 / 11$ & $\mathrm{p}>0.05$ \\
\hline BMI $\left(\mathrm{kg} / \mathrm{m}^{2}\right)^{\&}$ & $31.27 \pm 5.59$ & $24.44 \pm 4.13$ & $\mathrm{p}<0.01$ \\
\hline MAP $(\mathrm{mmHg})^{*}$ & $96.80 \pm 10.93$ & $95.33 \pm 9.53$ & $\mathrm{p}>0.05$ \\
\hline Haemoglobin $(\mathrm{g} / \mathrm{l})$ & $133.86 \pm 13.08$ & $146.45 \pm 15.42$ & $\mathrm{p}<0.01$ \\
\hline Urea $(\mathrm{mmol} / \mathrm{l})$ & $5.74 \pm 2.24$ & $4.52 \pm 1.50$ & $\mathrm{p}<0.05$ \\
\hline Creatinine serum $(\mu \mathrm{mol} / \mathrm{l})$ & $71.60 \pm 13.59$ & $71.25 \pm 13.89$ & $\mathrm{p}>0.05$ \\
\hline 24 hour urine CrCl $(\mathrm{ml} / \mathrm{min})^{\dagger}$ & $114.38 \pm 22.12$ & $112.48 \pm 22.22$ & $\mathrm{p}>0.05$ \\
\hline Cockcroft-Gault\# $(\mathrm{ml} / \mathrm{min})^{+}$ & $81.05 \pm 22.99$ & $132.96 \pm 39.59$ & $\mathrm{p}<0.01$ \\
\hline CKD-EPI $\left(\mathrm{ml} / \mathrm{min} / 1.73 \mathrm{~m}^{2}\right) \S$ & $86.53 \pm 14.96$ & $108.60 \pm 16.12$ & $\mathrm{p}<0.01$ \\
\hline Cystatin C $(\mathrm{mg} / \mathrm{l})$ & $0.96 \pm 0.22$ & $0.78 \pm 0.08$ & $\mathrm{p}<0.01$ \\
\hline Simple cystatin C $(\mathrm{mg} / \mathrm{l})$ & $109.63 \pm 20.47$ & $128.71 \pm 13.34$ & $\mathrm{p}<0.01$ \\
\hline Uromodulin $(\mathrm{ng} / \mathrm{ml})$ & $136.51 \pm 84.34$ & $220.50 \pm 92.39$ & $\mathrm{p}<0.01$ \\
\hline
\end{tabular}

${ }^{\$} \mathrm{~T} 2 \mathrm{DM}$ - diabetes mellitus type $2 ;{ }^{\text {\&BMI }}$ - body mass index; ${ }^{*} \mathrm{MAP}$ - Mean arterial pressure; ${ }^{\dagger} \mathrm{CrCl}$ - creatinine clearance; ${ }^{\star} \mathrm{Cockcroft}$ - Gault\#: Cockcroft-Gault for patients with BMI $<30 \mathrm{~kg} / \mathrm{m}^{2}$ and modificated Cockcroft- Gault ${ }_{\mathrm{LBW}}$ for patients with BMI $\geq 30 \mathrm{~kg} /$ $\mathrm{m}^{2} ;$ \& CKD-EPI - Chronic Kidney Disease Epidemiology Collaboration equation

Table 2. Univariate regression analysis with uromoduline as independed variable

\begin{tabular}{|l|c|c|}
\hline Parameter & Standardized Coefficients & $\begin{array}{c}\text { Significance } \\
\mathrm{p}\end{array}$ \\
\hline Age & $\beta(95 \% \mathrm{CI})$ & 0.000 \\
\hline Existence of T2DM & \\
\hline BMI $^{\&}$ & $-0.440(-0.360--1.222)$ & 0.000 \\
\hline Cockcroft-Gault\# $^{+}$ & $0.413(40.107-131.85)$ & 0.002 \\
\hline Cystatin C $^{\text {Simple cystatin C }}$ & $-0.359(-9.320--2.115)$ & 0.005 \\
\hline CKD - EPI & $0.330(0.259-1.426)$ & 0.01 \\
\hline
\end{tabular}

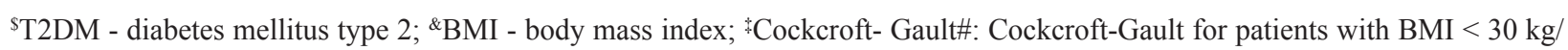

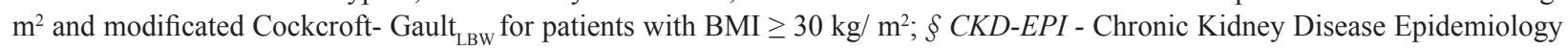
Collaboration equation

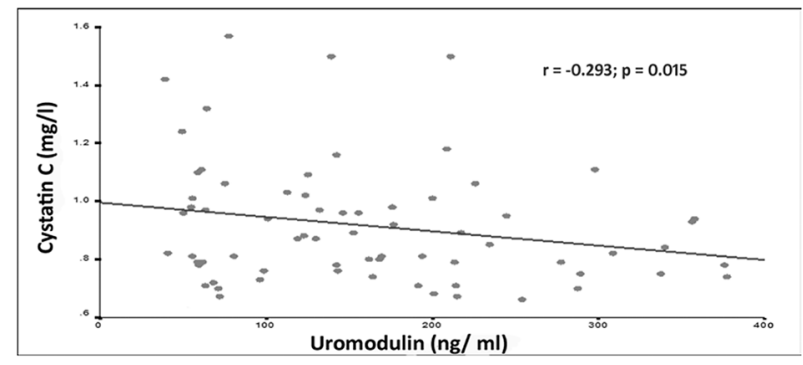

Figure 1. Correlation between serum concentration uromodulin and Cystatin $C$

patients were significantly older $(\mathrm{p}<0.01)$, had a significantly higher BMI $(\mathrm{p}<0.01)$ and serum urea concentration $(p<0.05)$, but lower haemoglobin serum concentration $(p<0.01)$ compared to controls. There was not found significant difference in sex $(p>0.05)$, MAP $(p>0.05)$, serum creatinine concentration $(p>$

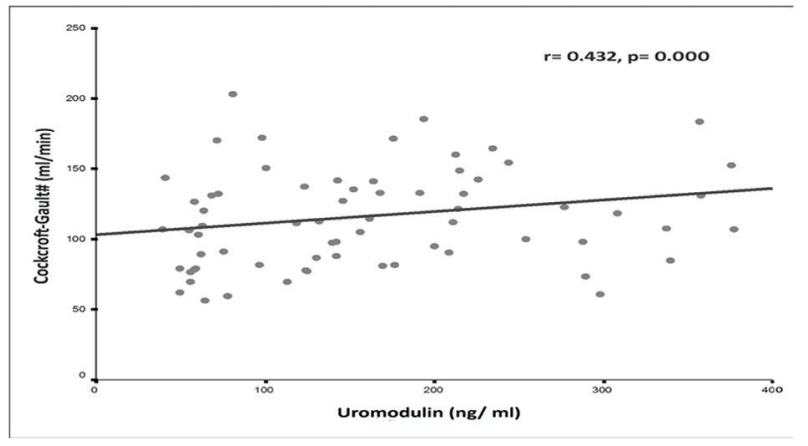

Figure 2. Correlation between serum concentration uromodulin serum and eGFR calculated by formula Cockcroft-Gault\#

$0.05)$ and 24 hour urine creatinine clearance $(p>0.05)$. T2DM patients had significantly lower eGFR calculated by formulas: Cockcroft- Gault\# $(\mathrm{p}<0.01)$ and 


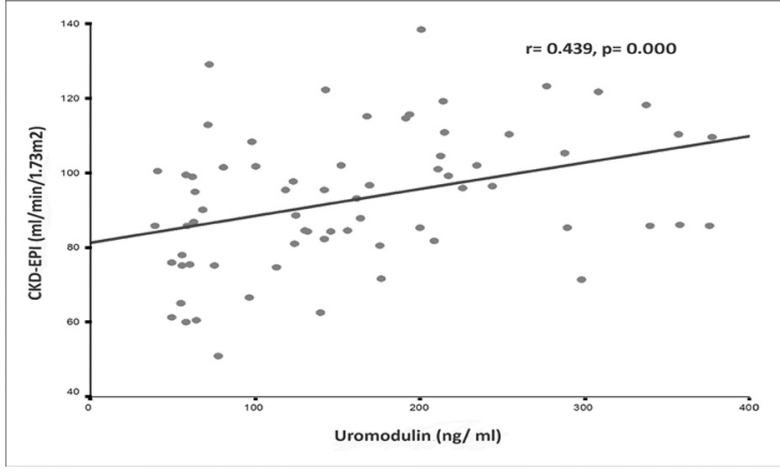

Figure 3. Correlation between serum concentration uromodulin serum and eGFR calculated by formula $C K D-E P I$

CKD- EPI $(\mathrm{p}<0.01)$ as well as simple cystatin $\mathrm{C}$ formula $(\mathrm{p}<0.01)$, but significantly higher the cystatin $\mathrm{C}$ serum concentration $(\mathrm{p}<0.01)$. In addition, the uromodulin serum concentration was significantly lower in T2DM patients than in controls $(\mathrm{p}<0.01)$ (Table 1).

Univariate analysis showed significant associations between uromodulin serum concentration and age $(p=0.000)$, existence of T2DM $(p=0.000)$, BMI ( $p$ $=0.002)$, cystatin $\mathrm{C}(\mathrm{p}=0.01)$, simple cystatin $\mathrm{C}(\mathrm{p}=$ $0.02)$, eGFR calculated by formulas: Cockcroft-Gault\# $(p=0.005)$ and CKD- EPI $(p=0.01)$ (Table 2). There were no associations between uromodulin and the duration of T2DM $(p>0.05)$. Multivariate analysis indicated that age is the most significant predictor of low uromodulin levels $(\beta=-0.449, \mathrm{p}=0.000)$ and with each year of age lowers the uromodulin, when adjusted for the multivariate regression analysis of the existence of T2DM, age remains the most important predictor of low uromodulin.

Significant negative correlation between uromodulin and age $(r=-0.476, p=0.000)$, BMI $(r=-0.313$, $\mathrm{p}=0.002)$ were found. Figure 1 shows significant negative correlation between uromodulin and cystatin C serum concentration $(r=-0.293, p=0.015)$. Significant positive correlation between uromodulin and eGFR calculated by formulas: Cockcroft Gault\# ( $\mathrm{r}=$ $0.432, p=0.000)$ (Figure 2) and CKD- EPI ( $r=0.439$, $\mathrm{p}=0.000)$ (Figure 3 ) as well as simple cystatin $\mathrm{C}(\mathrm{r}$ $=0.250, p=0.02$ ) were found. Diagnostic accuracy (area under the ROC curve) was 0.767 (95\% CI 0.652 $-0.883, \mathrm{p}<0.01)$. ROC showed that cut off point for serum uromodulin was 165 and this value provides sensitivity of $70 \%$ and specificity of $70 \%$ (Figure 4 ).

\section{DISCUSSION}

In the kidney, cells in the early distal convolute tubule and TAL of Henle's loop produced UMOD. The daily secretion of UMOD in healthy persons is about 20 - $70 \mathrm{mg}$. On the surface of the TAL cells,

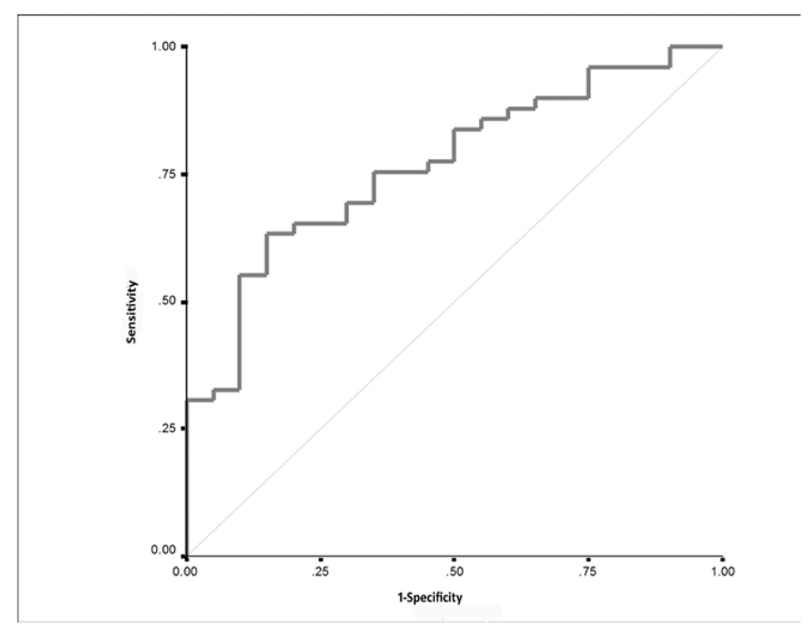

Figure 4. ROC curve analysis of serum concentration uromodulin

there could be a gel structure formed by UMOD. Uromodulin is released by a specific unidentified protease from the luminal side of the membrane (3). Some studies demonstrated that there is also a basolateral secretion of uromodulin; this mechanism is not still clear enough. Bachmann et al. (17) showed, using immuno- electron microscopy of the animal model of kidney, that the ratio of apical to basolateral uromodulin is $2: 1$. A study by Jennings et al. (18) proved that $10 \%$ of UMOD secretion is basolateral.

The urinary uromodulin concentration is higher than serum uromodulin concentration. No circadian rhythm was found for the uromodulin serum concentrations (19). As uromodulin is produced by cells of the TAL of Henle, a lower serum concentration of UMOD may influence the function of these cells in CKD. In CKD, secretion of UMOD increases by functioning nephron. The increase in urinary excretion is connected with the increase in basolateral secretion and the increase of serum UMOD concentration in CKD. Lower eGFR and a higher tubular atrophy score are connected to lower serum UMOD concentration (20).

Our study aimed to evaluate the uromodulin serum concentration in T2DM patients. The mean uromodulin serum concentration was significantly lower in T2DM patients compared to controls. T2DM patients had the serum creatinine concentrations in the reference range, as well as 24 - hour urine creatinine clearance, and there was no difference compared to controls. However, T2DM patients were significantly elderly, had higher BMI and higher cystatin $\mathrm{C}$ serum concentration, significantly lower eGFR calculated by formulas: Cockcroft- Gault\# and CKD-EPI. Although lower uromodulin serum concentration was in significant correlations with the duration of T2DM, higher BMI, eGFR calculated by those formulas, multivariate analysis indicated that age is the most significant pre- 
dictor of low uromodulin levels. ROC showed that the cut-off point for serum uromodulin was 165 , and this value provides the sensitivity of $70 \%$ and specificity of $70 \%$.

To date, most studies have investigated the association of urinary uromodulin concentration with markers of kidney function and eGFR. Little is known about the significance of serum uromodulin concentration. Risch et al. (19), in the cohort study of 289 healthy participants (mean age $71 \pm 7$ years), investigated the uromodulin serum concentration. In this study, the association between uromodulin and age was significantly negative but between uromodulin and eGFR significantly positive which agrees with our findings. Age-related changes in renal structure and functions have been described, and they are not the only consequence of aging but also of hypertension, diabetes mellitus, and the frequency of glomerulosclerosis progressively increased to $30 \%$ after the eighth decade of life. Baltimore's longitudinal study (21) showed that after the third decade of life, eGFR decreased by $8 \mathrm{ml} / \mathrm{min}$ per decade. Dawnay and Cattel's study (22) showed that anephric patients and some patients on hemodialysis had immeasurable concentrations of UMOD; serum concentration of UMOD decreased after unilateral nephrectomy. However, patients who had received transplants exhibited increased uromodulin serum concentrations (22). Our findings on the positive relationship between serum uromodulin and kidney function agree with those of Thornley et al. (20) and Dawney and Cattel (22) and contrast those to Prajczer et al. (23). Prajczer et al. (23) found an inverse relationship between serum uromodulin and eGFR.

Prajczer (23) studied patients with kidney biopsy-proven various glomerular diseases. In this glomerulonephritis, as inflammatory kidney diseases, basolateral secretion of uromodulin could be increased and furthermore could lead to higher serum concentrations despite a decrease in eGFR.

\section{CONCLUSION}

The results of the present study indicate that T2DM patients, after 5-30 years of follow-up with serum creatinine concentration and $24 \mathrm{~h}$ urine creati- nine clearance in the reference range, had significantly lower uromodulin serum concentration, lower eGFR calculated by formulas: Cockcroft-Gault\# and CKDEPI compared to controls. These results indicate that T2DM patients had impaired renal function initially, which was not detected only by determining serum creatinine and 24-hour urine creatinine clearance. The most significant predictor of low values of uromodulin, except the existence of T2DM, was age. Although the role of serum uromodulin concentration is not fortified yet, the results of this study show that reduced uromodulin serum concentration indicates early kidney damage in T2DM patients. So serum uromodulin could predict renal injury earlier when compared to conventional kidney function markers -serum creatinine and formulas: Cockcroft-Gault and CKD-EPI.
Abbreviations
AKI - acute kidney injury;
BMI - Body mass index;
CKD - chronic kidney disease;
CKD - EPI - Chronic Kidney Disease Epidemi- ology Collaboration equation;
$\mathrm{CrCl}$ - creatinine clearance;
DBP - diastolic blood pressure;
eGFR - estimated glomerular filtration rate;
MAP - mean arterial pressure;
ROC - receiver operating curve;
SBP - systolic blood pressure;
SNP - single-nucleotide polymorphism;
TAL - thick ascending limb;
T2DM - type 2 diabetes mellitus;
UMOD - Uromodulin

\section{Acknowledgment}

None.

Conflict of Interests: The authors declare no conflicts of interest related to this article.

\section{Funding: None}

\section{Licensing}

This work is licensed under a Creative Commons Attribution 4.0 International (CC BY 4.0) License. 


\title{
Sažetak
}

\section{ZNAČAJ ODREĐIVANJA KONCENTRACIJE UROMODULINA U SERUMU BOLESNIKA SA DIJABETES MELITUSOM TIP 2}

\author{
Jordanova Elena, ${ }^{1}$ Samardzic Vladimir, ${ }^{2}$ Pekovic-Perunicic Gordana, ${ }^{1}$ \\ Tica-Jevtic Jelena, ${ }^{2}$ Simic-Ogrizovic Sanja ${ }^{3,4}$

\footnotetext{
${ }^{1}$ Department of Nephrology, Clinic for Internal Medicine, Clinical Hospital Center Zemun, Belgrade, Serbia ${ }^{2}$ Department of Endocrinology, Clinic for Internal Medicine, Clinical Hospital Center Zemun, Belgrade, Serbia ${ }^{3}$ Medigroup Hospital, New Belgrade, Belgrade, Serbia

${ }^{4}$ University of Banja Luka, School of Medicine, Banja Luka, Bosnia and Herzegovina
}

Uvod. U bubregu, tubulske ćelije ushodnog kraka Henleove petlje sekretuju uromodulin (UMOD). Cilj ove studije je ispitati koncentraciju uromodulina u serumu pacijenata sa dijabetes melitusom tip 2 (T2DM) u ranom otkrivanju oštećenja bubrega.

Materijal i Metode. Studija je obuhvatila 50 T2DM pacijenata starosne dobi $60,75 \pm 11,23$ godina sa jačinom glomerulske filtracije (JGF)114,38 $\pm 22,12$ $\mathrm{ml} / \mathrm{min}$ i kontrolnu grupu 20 zdravih osoba. Merili smo serumsku koncentraciju hemoglobina, uree, kreatinina, uromodulina (ELISA metoda) i cistatina $\mathrm{C}$ (nefelometrija). Odredili smo formule: Cockcroft-Gault\# (kombinacija Cockcroft-Gault za pacijente sa BMI $<30 \mathrm{~kg} / \mathrm{m}^{2}$ i Cockcroft-Gault ${ }_{\text {LBW }}$ za pacijente sa BMI $\geq 30 \mathrm{~kg} / \mathrm{m}^{2}$ ), CKD-EPI (Chronic Kidney Disease Epidemiology Colaboration equation) i simple Cistatin $\mathrm{C}$.

Rezultati. T2DM pacijenti su imali nižu koncentraciju hemoglobina u serumu kao i JGF određenu

\section{REFERENCES}

1. Micanovic R, LaFavers K, Garimella P, Wu X, El-Achkar TM. Uromodulin (Tamm- Horsfall protein guardian of urinary and systemic homeostasis). Nephrol Dial Transplant. 2020; 35(1): 33-43. doi: 10.1093/ndt/gfy394.

2. Kipp A, Olinger E. What does uromodulin do? Clin J Am Soc Nephrol. 2020 ;16(1):150-3. doi: 10.2215/CJN.06390420.

3. El- Achkar TM, Wu XR. Uromodulin in kidney injury: an instigator, bystander, or protector? Am J Kidney Dis. 2012; 59 (3): 452-61. doi:10.1053/j.ajkd.2011.10.054.

4. Leiherer A, Muendlein A, Saely CH, Kinz E, Brandtner EM, Fraunberger $P$ et al. Serum uromodulin is associated with impaired glucosae metabolism. Medicine (Baltimore). 2017; 96 (5): e5798. doi: 10.1097/MD.0000000000005798.

5. Xu X, Barreiro K, Musante L, Kretz O, Lin H, Zou H et al. Management of Tamm- Horsfall Protein for reliable urinary analytics. Proteomics Clin Appl. 2019;13(6): e1900018. doi 10.1002/prca.201900018.

6. Säemann MD, Weichart T, Zeyda M, Staffler G, Schunn $\mathrm{M}$, Stuhlmeier KM et al. Tamm-Horsfall glycoprotein links innate immune cell activation with adaptive immunity via a Tolllike receptor-4-dependent mechanism. J Clin Invest. 2005; 115: 468-75. doi: 10.1172/JCI22720.

7. Pfistershammer K, Klauser C, Leitner J, Stöckl J, Maidic $\mathrm{O}$, Weichhart $\mathrm{T}$ et al. Identification of the scavenger receptors formulama: Cockcroft- Gault\# i CKD-EPI. T2DM pacijenti su imali značajno viši BMI i cistatin $\mathrm{C}$ u poređenju sa kontrolnom grupom. T2DM pacijenti su imali značajno nižu serumsku koncentraciju uromodulina $(136,51 \pm 84,34$ vs $220,50 \pm 92,39 \mathrm{ng} / \mathrm{ml})$ nego u kontrolnoj grupi. Pronađena je značajno pozitivna korelacija između uromodulina i formula: Cockcroft- Gault\# $(r=0,432, p=0,000)$ i CKD- EPI $(r=0,439 ; p=0,000)$ kao i simple cistatina $\mathrm{C}(\mathrm{r}=0,250, \mathrm{p}=0,02)$, a negativna korelacija sa starošću $(r=-0,476, p=0,000)$, BMI $(\mathrm{r}=-0,313, \mathrm{p}=0,002)$ i serumskom koncentracijom cistatina $\mathrm{C}(\mathrm{r}=-0,293, \mathrm{p}=0,015)$.

Zaključak. Uloga koncentracije uromodulina u serumu još nije utvrđena. Rezultati ove studije pokazuju da smanjena koncentracija u serumu ukazuje na rano oštećenje bubrega kod T2DM pacijenata.

Ključne reči: klirens kreatinina, cistatin $\mathrm{C}$, dijabetes melitus, JGF, uromodulin.

SREC-I, Cla- 1 (SR-BI), and SR- AI as cellular receptors for Tamm- Horsfall protein. J Leukoc Biol. 2008; 83 (1): 131- 8. doi: 10.1189/jlb.0407231.

8. Lou NJ, Ni YH, Jia HY, Deng JT, Jiang L, Zheng FJ et al. Urinary microvesicle- bound uromodulin: a potential molecular biomarker in diabetic kidney disease. J Diabetes Res. 2017; 2017: 3918681. doi: 10.1155/2017/3918681.

9. Leiherer A, Muendlein A, Saely CH, Brandtner EM, Geiger K, Fraunberger $\mathrm{P}$ et al. The value of uromodulin as a new serum marker to predict decline in renal function. J Hypertens. 2018; 36(1): 110-8. doi: 10.1097/HJH.0000000000001527.

10. Lhotta K. Uromodulin and chronic kidney disease. Kidney Blood Press Res. 2010; 33(5): 393- 8. doi: 10.1159/000320681.

11. Magder S. Volume and its relationship to cardiac output and venous return. Crit Care. 2016; 20(1): 271. doi: 10.1186/s13054-016-1438-7.

12. Shahbaz H, Gupta M. Ceatinine Clearance [Updated 2021 Jul 26]. In: StatPearls [Internet].Treasure Island (FL): Stat Pearls Publishing; 2021 Jan.

13. Rhee J, Kwon JM, Han SH, Kim SH, Park CH, Jeon $\mathrm{JH}$ et al. Cockcroft-Gault, modification of diet in renal disease, and chronic kidney disease epidemiology collaboration equations for estimating glomerular filtration rates in cancer patients receiving cisplatin-based chemotherapy. Kidney Res Clin Pract. 2017; 36(4): 342-8. doi.org/10.23876/j.krcp.2017.36.4.342. 
14. Friesen JHP. Propofol pharmacokinetic model and lean body weight scalar for dose estimation in morbid obesity. Br J Anaesth. 2019; 123(2): e159-e160. doi: 10.1016/j. bja.2019.04.047.

15. Zafari N, Churilov L, Maclaac R, Tourkami N, Baxter $\mathrm{H}$, Kiburg K et al. Diagnostic performance of the Chronic Kidney Disease Epidemiology Collaboration (CKD-EPI) equation at estimating glomerular filtration rate in adults with diabetes mellitus: a systemic review and meta-analysis protocol. BMJ Open 2019; 9:e031558. doi:10.1136/bmjopen-2019-031558.

16. Inker LA, Eneanya JC, Coresh J, Tighiouart H, Wang D, Sang Y et al. New creatinine - and cystatin C- based equations to estimate GFR without race. N Engl J Med. 2021; 385(19): 1737-49. doi: 10.1056/NEJMoa2102953.

17. Bachmann S, Koeppen- Hagemann I, Kriz W. Ultrastructural localization of Tamm- Horsfall glycoprotein (THP) in rat kidney as revealed by protein A-gold immunocytochemistry. Histochemistry. 1985; 83(6): 531-8. doi: 10.1007/BF00492456.

18. Jennings P, Aydin S, Kotanko P, Lechner J, Lhotta K, Williams $\mathrm{S}$ et al. Membrane targeting and secretion of mutant uromodulin in familial juvenile hyperuricemic nephropathy. J Am Soc Nephrol. 2007; 18 (1): 264-73.

19. Risch L, Lhotta K, Meier D, Medina-Escobar P, Nydegger UE, Risch M. The serum uromodulin level associated with kidney function. Clin Chem Lab Med. 2014; 52(12): 175561. doi: 10.1515/cclm-2014-0505.

20. Thornley C, Dawnay A, Cattell WR. Human TammHorsfall glycoprotein: urinary and plasma levels in normal subjects and patients with renal disease determined by fully validated radioimmunoassay. Clin Sci. 1985; 68 (5): 529-35. doi: $10.1042 / \operatorname{cs} 0680529$.

21. Lindeman RD, Tobin J, Shock NW. Longitudinal studies on the rate of decline in renal function with age. J Am Geriatr Soc. 1985; 33(4): 278-85. doi: 10.111/j.1532-5415.1985.tb07117.x.

22. Dawnay AB, Cattel WR. Serum Tamm- Horsfall glycoprotein levels in health and renal disease. Clin Nephrol. 1981; 15(1): 5-8.

23. Prajczer S, Heidenreich U, Pfaller W, Kotanko P, Lhotta K, Jennings P. Evidence for a role of uromodulin in chronic kidney disease progression. Nephrol Dial Transplant. 2010; 25(6): 1896-903. doi: 10.1093/ndt/GFP 748.

\section{Correspondence to/Autor za korespondenciju \\ Elena Jordanova, $\mathrm{MD}, \mathrm{PhD}$ \\ Department of Nephrology, Clinic for Internal Medicine, Clinical Hospital Center Zemun \\ Vukova 9, 11080 Zemun, Belgrade, Serbia \\ Email: jordanova.elena@gmail.com \\ Phone: +381113772 716}

How to cite this article. Jordanova E, Samardzic V, Pekovic-Perunicic G, Tica-Jevtic J, Simic-Ogrizovic $\mathrm{S}$. The importance of determing the uromodulin serum concentration in diabetes mellitus type 2 patients. Sanamed..2021;16(3): 201-207. 